\title{
Wellfare Culture The English Riots And The Collapse Of Authority
}

\author{
Stuart Waiton
}

\section{INTRODUCTION}

During and especially after the riots in England the question that appeared to preoccupy the minds of the various television and radio presenters north of the border was, 'Why are there no riots in Scotland?' This sudden press pride in Scottish youth was somewhat ironic given the Scottish media's usual love of all things 'knife', 'gang' and 'violence' (especially when it is associated with 'sink estates', and 'Neds', often laced with a heady cocktail of drugs, 'binge drinking' and most recently with Old Firm football fans). Somehow, the usual anxiety and bluster about the violent nature of Scotland's poor and young was transformed overnight into something of a love-in. Scotland it seemed was special, different and, by implication, better than England.

In many respects Scotland is in fact very similar to England, having similar anxieties, concerns about antisocial behaviour, crime, gangs and so on, and similar in terms of the new laws that have been, and are being, introduced to regulate many types of behaviour that are deemed to be problematic. Local authorities in Scotland have 'community safety' as one of their strategic objectives; Hamilton introduced one of the first curfews in the UK in 1997 under the guise of the 'Child Safety Initiative'; Scotland was often ahead of the game when introducing CCTV schemes to city centres and housing estates; zero tolerance policing was strongly promoted in Strathclyde for many years, while 'community policing' has been developed across all regions. Some of these developments are specific to policing and safety initiatives north of the border, but in the main they reflect developments in the UK as a whole.

Stuart Waiton is a lecturer in Sociology at Abertay University. 


\section{Wellfare Culture The English Riots And The Collapse Of Authority}

Scotland, thanks largely, but not exclusively, to estates in Glasgow, has some of the worse areas of deprivations not only in the UK but also in Europe, and indeed, thanks to researchers and writers like Carol Craig (2010), there is an image of Scotland, or at least parts of it, that makes the days of the 'No mean city' look like a tea party. Again then, in terms of social problems, tensions, and potential flash points that could perhaps encourage alienation and rioting, Scotland appears to be well-placed to face such problems.

Nevertheless, there were no riots in Scotland; indeed compared with England in the post-war period there have been relatively few examples here of rioting and looting, and as such there is still an argument to be had about the significance of this fact.

Today, however, is not yesterday, and despite some attempts to understand the current rioting with reference to the past and in particular with reference to events in the 1980s, despite some current similarities with these notorious race riots, there is arguably more that separates these events than unites them. Before looking at the Scottish dimension it is therefore necessary to examine what the 2011 riots were actually about. What caused them? Why did they spread? And in this respect why, if at all, can we argue that Scotland is a different place to England?

\section{ZOMbIE CAUSES AND CATEgORIES}

When times change, as Jean Baudrillard (1983) has observed, old frameworks through which society previously operated are transformed; however the words, terms and categories we use often stay the same, as we attempt to understand the present with reference to the past. Consequently we end up with what can be called zombie categories, categories that appear to have weight and meaning but in reality are empty. Where once these categories related to real social, political and cultural developments, and also institutions and movements in society, as times change they become less real, less solid, and, like the first little pig's house of straw, shaky, unconvincing and unstable.

So it has been with much of the discussion about the riots, especially from liberal and more left wing thinkers. Where discussion about the 1980s riots about police harassment, systematic racism, an aggressive establishment, and a fight-back against inequality - all had a certain reality to them, today the attempt to understand the riots, the police and the elite's reaction to events 
with these words, terms and categories is unhelpful, confused and often meaningless.

The catchall weasel word 'neoliberal' has been dragged out time and again to explain everything and nothing about the riots. 'London rioters are Thatcher's grandchildren', explained one commentator. ${ }^{1}$ Likewise for the Guardian's main feature writer Polly Toynbee the rioters were part of a 'neoliberal amoral creed'. The bankers are greedy, our culture is greedy, hey presto the rioters are greedy and that is why this all happened. The New Statesman while covering the riots from a number of more useful angles carried a leading article by Victor Adebowale entitled, 'Poverty isn't an excuse for the riots. It's a reason'. ${ }^{2}$ Logically following this argument was the idea that, as Ken Livingston argued on BBC's 'Newsnight', the cuts were to blame: 'If you're making massive cuts, there's always the potential for this sort of thing'. Even the eminent sociologist Zygmunt Bauman focused upon the question of inequality or, more accurately, upon the notion of our consumer society, arguing that 'These are not hunger or bread riots. These are riots of defective and disqualified consumers'. ${ }^{3}$

As with almost any explanation about a social event or phenomena, there is arguably truth in all of the above explanation. However, especially on the left, there is a rather unconvincing and unhelpful attempt to lazily lump everything together, bankers, greed, MPs' expenses, the cuts and so on, with the riots. But this approach lacks specificity, both historically, and also in terms of analysing the actions and nature of the rioters in their own right. Discussing the riots with colleagues, it was almost as if there was a desperate attempt to find some sense of certainty by collectively shouting, 'It's Capitalism That Done It'. This

\footnotetext{
${ }^{1}$ http://www.delawareonline.com/article/20110815/OPINION16/110812006/PankajMishra-London-s-rioters-Thatcher-s-grandchildren?odyssey $=$ mod\%7Cnewswell\%7Ctext\%7CHome\%7Cs [accessed $16^{\text {th }}$ Sept 2011]

${ }^{2}$ http://www.newstatesman.com/blogs/the-staggers/2011/09/riots-society-socialpoverty [accessed 19th Sept 2011]

${ }^{3}$ http://www.social-europe.eu/2011/08/the-london-riots-on-consumerism-cominghome-to-roost/

[accessed $19^{\text {th }}$ Sept 2011]. There is however a benefit to Bauman's discussion about 'consumers' rather than inequality or cuts, and that is in his post modernist recognition that society has become more empty and meaningless.
} 


\section{Wellfare Culture The English Riots And The Collapse Of Authority}

may make people feel a little cosier amongst their 'radical' colleagues, but in the real world it is unlikely that these leftist arguments make us feeling safer at night as we head towards our straw homes.

In one way of course capitalism did do it, just as in the same broad sense it has done pretty much everything for the last two centuries, but understanding the nature of today's elites, major institutions like the police 'service', communities and the type of young people who were seen on the riots cannot be explained simply by pointing a rather limp finger at capitalism. Rather, as this article attempts to argue, it is more important to look at what the state, state employees, practices and professionals have been doing since the 1980s to transform the welfare state into what I would define as our new wellfare state - a more interventionist, regulatory, 'supportive' state centred around the more therapeutic notion of well-being.

Usefully, looking at the idea that spending cuts were responsible for the riots, the criminologist Dr Marian Fitzgerald made the simple observation that the vast majority of the proposed government cuts had not been carried out when the disturbances took place. ${ }^{4}$ Consequently, the understanding, or perhaps what is more in reality a rhetorical political argument, about government spending being responsible for the riots appears to lack credibility. Regarding the issue of race and racism, Fitzgerald was also usefully empirical, noting with reference to arguments about, 'Too many black men have been killed by the police', ${ }^{5}$ that in fact police shootings are very rare, and that in the last three years, 'there have been only seven [people shot dead by the police] and all of these ... were white people'.

The race issue is worth noting, not to dismiss out of hand the idea that there are tensions and even problems with policing of some black areas, but to recognise how different things are today compared with the race riots of the 1980 s. What is interesting about the recent riots is not that there were no black people involved - there were many - but that few people, even conservatives, drew attention to this. There was little if any talk of the 'enemy within' in

\footnotetext{
${ }^{4}$ http://www.bbc.co.uk/news/magazine-14483149 [accessed 19 ${ }^{\text {th }}$ Sept 2011]

${ }^{5}$ Argued in the Independent newspaper

http://www.independent.co.uk/opinion/commentators/christina-patterson/christinapatterson-we-cant-deny-that-race-plays-a-part-2334813.html [accessed 19th Sept 2011]
} 


\section{Scottish Affairs}

terms of immigrants and their alien culture, nor were there chief police officers like the no nonsense Kenneth Newman arguing that Jamaican's were 'constitutionally disorderly' (Tompson 1988, p. 21).

As we will discuss, the current riots were of interest more because of the profound differences in the nature of the riots themselves, and equally in the nature of the response to them. In many respects the arguments and understanding of the riots are too general. The attempt to compare them and find common ground with past riots, using old categories, often misses what is new today, and indeed to confuse rather than clarify what we were actually witnessing on the streets in England. At the same time however, when new aspects of the riots, for example the use of Blackberries and Facebook, are discussed they have been discussed in an overly fetishlike and technical way, as if new technological developments in and of themselves can explain anything. Rather, the very fact that technophobic reactions have developed is less illustrative of the significance in the rise of technology and more a reflection of a declining sense of both adult and 'establishment' authority.

\section{THE RIOTS OF 2011}

Without giving a chronology of events it is worth simply looking at what actually happened in parts of England after the police shooting of Mark Duggan.

Following the shooting and the vigil that Duggan's family and friends organised outside Tottenham police station disturbances developed and eventually something that could be described as a riot began. Over the next few days, Tottenham, Enfield, Dalston and Croydon, all in London, had seen rioting, looting and buildings being burnt. This then spread to parts of Nottingham, Leeds, Manchester and Birmingham. Apart from the initial vigil and anger at the police in Tottenham none of these eruptions appeared to have a political context, or at least not one that was articulated or clearly related to a collective form of disgruntlement. Even in terms of anger against the police there was little expression of this. The police reaction was, at least in comparison to past forms of riot policing, relatively hands-off, and there were regular complaints, aired on television and in the media, of the police standing back while shops were looted and buildings set on fire. As one critical observer noted, 
One Met commander gave a revealing interview to Sky News, explaining that the policing of communities had changed a lot since the riots of 25 or 30 years ago. This time, he said, 'we're standing next to these people watching them cry because their businesses have been destroyed. We're going to work with the partners in that local community to make sure we help them rebuild Tottenham. That's what policing is all about. ${ }^{6}$

As calls went up from the Sun newspaper and others to bring out the water canons and to stop being 'squeamish' about the use of force, there did for a few days appear to be an almost unstoppable form of lawlessness taking place, despite the fact that there were, David Cameron argued, 16,000 police officers on the streets. Indeed, with outrage growing about a lack of a coherent government and police response Cameron, and particularly Theresa May, were somewhat lost for words. Where words were found, like the promoted idea that there had been and would be 'robust' policing, or that the 'appropriate' use of force would be used, both politicians and perhaps especially the police appeared to have developed a form of linguistic correctness regarding even people who were burning down city shops and destroying parts of their own communities.

Despite this sense of, at times, complete lawlessness, it is worth noting that compared with a number of the riots in the 1980s, perhaps especially the one in Broadwater Farm, the 2011 events were often relatively minor affairs, far less organised, if at all, and often far less violent. In Broadwater Farm for example a genuine battle took place between tooled up young black men and what was eventually 9,000 riot police, the result being that a police officer was brutally killed and around a tenth of the population of the estate were arrested.

Looking at events in 2001, at one level the action of the police and authorities could be described as defensive rather than offensive, both in the direct policing of the rioters and looters and also in their advice to people during the riots, especially shopkeepers who were told to board up their property. One advantage of Facebook during this period was the constant description of events on the streets from friends who wrote with some shock about the way London, one of the major cities of the world, had been turned into a ghost town as shopkeepers, landlords and restaurateurs closed and boarded their property. Even places like Madame Tussauds closed their doors to the public,

\footnotetext{
${ }^{6}$ http://www.spiked-online.com/index.php/site/article/10973/ [accessed $19^{\text {th }}$ Sept 2011]
} 


\section{Scottish Affairs}

as did the main retail shops, pubs and corner shops. Whereas few people directly witnessed the riots themselves, almost everybody in central London experienced the closing down of London, something that, as one observer noted, had not occurred even during the Blitz.

With 24 hour television there was also the unusual development of reporting and even discussions taking place with rioters as the riots took place. The fact that the rioters seemed more than happy to chat away to journalists was also somewhat strange, as was their casual honesty. One young black youth interviewed in Manchester simply explained that it was obvious that the police weren't doing much about what was going on so he thought, 'I'll have some of that'. Some of those involved in the riots were clearly being opportunistic, taking advantage of what looked like a golden opportunity to raid some shops. Indeed, again unlike many riots in the past, looting appeared to be the aim and end in itself, rather than an off-shoot or a by-product of a more social, politically or even communally grounded anger.

In this respect the discussion about a consumer driven riot appears to have some weight as a key aspect of the rioting was looting of shops; indeed this was arguably the only thing many of those involved did. However, even here, it is less than clear that this could be seen as serious looting or an attempt to 'get things' as 'consumers'. The rioting and looting became the top story in the UK for over a week and one of the top international stories across the world. Consequently there was a plethora of television, radio and press coverage, images, interviews and debates covering this story. A curious picture of the rioters was built up, where time and again the looting seemed for many of the participants to be a bit of a laugh, with pleasure gained more in the act of trashing the shop and grabbing something than from what was actually taken. It is also the case that there was little monetary value involved in terms of shops that were targeted. Some people arrested after the event were charged with 'stealing a bottle of water', or for 'stealing chewing gum' (this individual received a six month jail sentence). Janet Daley in the Telegraph arguing for stiffer penalties for those involved, noted that this should be the case even though many were acting more like 'idiots rather than like professional criminals' (Telegraph $17^{\text {th }}$ August 2011). Some of the rioters appear to have simply given their 'stuff' away, in one case leading to a women being given a prison sentence for receiving a stolen pair of shorts from the riot 


\section{Wellfare Culture The English Riots And The Collapse Of Authority}

(this sentence was later over turned). ${ }^{7}$ These cases may have been extreme examples used to question the sentencing being given. However, the overall picture, partly assisted by the inaction of the police, was of a casual, immature form of behaviour, more akin to a game of chap the door and run, than of serious criminality.

Apart from the more serious and opportunistic criminals who also took a ride on the back of the riots, for the 'general' rioter, materialistic, 'greedy' and consumer driven concerns did not appear to be a serious driving force for their actions.

As looting was probably the main characteristic of these riots, stealing was of some importance. Watching the somewhat chaotic but also smiling faces of the rioters as they raided shops, the term looting is indeed more useful than stealing. The destructiveness of the process and the fun of being able to do what you wanted was clearly part of what was taking place. Again this appears to be different from past riots, in terms of the relatively limited expression of anger being shown by those involved. Not in all cases, but regularly and arguably for the most part, there was a kind of childishness and a lack of seriousness about the rioters: it appeared as little more than a game or just an extreme form of 'messing about'. At one level the rioters did not appear to really get it, to realise that they were actually involved in something serious called a 'riot'.

Finally, and of some significance for understanding what was new about these riots, a somewhat shocking and depressing aspect of the riots was the complete lack of community connection displayed by those involved. Despite the destructiveness of past British riots in recent years, and particularly in the 1980 s, the violence and rioting that occurred then could be seen, at least in part, as an overspill of wider community concerns, tensions and anger. As such, these past riots reflected a form of community action or eruption. In comparison the 2011 riots had no community involvement or anger being expressed; in fact the individuals involved appeared to be just that, individuals, with no concern for the destruction of their own community, nor indeed any collective sense with their fellow looters.

${ }^{7}$ http://www.guardian.co.uk/commentisfree/libertycentral/2011/sep/09/riotsdisproportionate-increase-sentencing [accessed 26th Sept 2011] 


\section{Scottish Affairs}

The now famous video entitled, 'Truly extraordinary speech by West Indian woman in face of Hackney riots', showing a black woman with a walking stick shouting with contempt and rage at the immature rioters for destroying their own community rather than fighting for a cause is illustrative of what the riots were and were not about. As this woman argued while staring at local shops being burned to the ground,

She's working hard to build her business up and you want to burn it up and for what, so you can say you're 'warring' and being a 'bad man'

... This is about a fucking man shot in Tottenham not about having fun and busting up the place ... Get real. If we're fighting for a cause, fight for a cause ... You people piss me the fuck off. I'm ashamed to be a Hackney woman because we're not all gathering together we're running down Foot Locker. $^{8}$

After her speech this woman contemptuously turned her back on the rioters and walks off.

\section{THEN AND NOW}

That it was 30 years since the Brixton riot of 1981 led some commentators to note the similarities to recent events. Not only did we have riots in London but we had and have high youth unemployment, major economic problems and what appears to be a reaction to this. We even had a Royal wedding in the summers of 1981 and 2011, a perfect contrast perhaps between the lives of the haves and the have nots.

Alternatively however, relating to the early 1980 s, it is once again the differences rather than the similarities of this period that are striking - literally 'striking' - or in the case of 2011 - not striking. Then, unlike today, politics was dominated by left and right, by a newly emerged and forceful Conservative party and a still powerful labour movement and a variety of socialist ideas and organisation within and out with the Labour Party. We had just experienced the Winter of Discontent and continued to see major strikes across many industries. The battle of left and right, which was at times both violent and on a mass scale, was replicated internationally with a revitalised tension in the Cold War when Ronald Reagan emerged as president of the

\footnotetext{
${ }^{8}$ http://www.twitvid.com/4JTZH [accessed 20th Sept 2011]
} 


\section{Wellfare Culture The English Riots And The Collapse Of Authority}

United State of America. In Britain we had a more aggressive form of nationalism illustrated in the Falklands war and the reaction to it with the subsequent re-election of Margaret Thatcher. British nationalism was also of some significance in heightening racial tensions in inner city areas, where issues of illegal immigrants and forms of policing in part led to a number of riots in largely black areas.

The Royal wedding of Prince Charles and Lady Diana Spencer and the 2011 wedding of Prince William and Catherine Middleton are also of interest because of the difference of what was a classical, national and Royal event then, compared with the more celebrity type wedding of 'William and Kate', which was ridiculed by significant sections of the cultural elite, the press and even sections of the political elite. Even Royal weddings it seems are less inclined to bring the nation together, to even bring what was once called the establishment together, than to be treated with irony, disregard and cynicism.

If the 'old left' has long gone from British political life, aspects of the 'old right' are also far more circumscribed today. Overt British nationalism (which was in fact something that was part of both of these camps, if more associated with the right) is far more problematic in our multi-cultural times. Indeed, forms of nationalism that were commonplace in the eighties are now often described in terms of 'extremism', with organisations like the English Defence League being roundly condemned by all sides, while the Scottish Defence League have been banned from marching in Edinburgh once again this year.

The significance of these changes for understanding the riots is that the framework of meaning that informed the action of both the rioters and the actions of the authorities in the past no longer carries much, if any, weight.

\section{Police Authority}

Aspects of policing and the role of the police in the 1980s were visibly authoritarian and at times overtly racist - with reactionary chief police officers like James Anderton who was nicknamed 'God's Copper' and argued that homosexuality should be illegal, and Sir Kenneth Newman who was infamous for his racist views - being par for the course at this time. Today via the MacPherson report and wider changes to the 'community' friendly police 
service (rather than force), the more overt forms of policing are often confused. ${ }^{9}$

In the television police drama 'Life on Mars' a fascination ending to the series saw the new age and politically correct officer who had found himself shot back in time to the offensive, macho and violent policing days of the 1970s in an ironic dilemma. Having returned to the $21^{\text {st }}$ century Sam Tyler discovered when entering a police committee meeting that the individuals in the room appeared somehow passionless and empty, talking in a bureaucratic and technical language that he could barely understand let alone relate to. This visionless, 'service', preoccupied by 'process', lacked meaning to even Tyler who clearly preferred the camaraderie of his by-gone colleagues to the extent that he threw himself off the building in an attempt to go back in time once again. Watching the riots develop, spread and erupt, I found myself in a similarly ironic state, not wanting to go back to the, at times, brutal racist police force of the $1980 \mathrm{~s}$, but feeling that there was something clearly worrying about riot police who appeared impotent in the face of a riot.

As the ex-Conservative MSP Brian Montieth noted,

We have been able to watch police standing in serried ranks observing the rioting going on just a matter of yards in front of them and doing nothing, not stepping forward to even move them on, never mind whipping the legs from under them and cuffing them and taking them away (Scotsman $12^{\text {th }}$ August 2011).

Not surprisingly, when advised by the police to board up their shops and go home, shopkeepers across London drew the conclusion that the police were telling them that they could no longer protect their property. Similarly, groups of Asians drew the conclusion that they would have to protect their own shops and mosques as did a crowd of white working class men in Enfield. ${ }^{10}$ The

\footnotetext{
${ }^{9}$ Leading at times to the bizarre stand off form of authoritarianism known as kettling; or to reactive events like the shooting of Charles de Menezes or to the stand off displayed during the riots.

${ }^{10}$ The discussion about these two groups of vigilantes was telling as the Asian group were treated with far more sympathy than the white working class Enfield men who sang England songs and were dismissed by many as racists and as even more of a problem than the rioters themselves. In our wellfare world, autonomous action and self activity have become increasingly demonised.
} 
significance of the lack of police action especially in the early stages of the riots is that it was in part, and arguably in large part, this very inaction that led to the subsequent rioting and looting.

Another black youth interviewed on Sky News, explaining why he was rioting, 'It's the government,' he said. The reporter was clearly expecting the next sentence from this rioting young man to be about the cuts, but no. It was much simpler than that. 'The government has no authority,' he stated. Indeed it was not Facebook that encouraged the riots so much as good old TV pictures of riot police standing back while shops were raided and set on fire. The sense of retreat and defensiveness by the police was palpable in relation to the rioters and also in their encouragement of shops to close, and even their unconvincing language of 'robust' and 'appropriate' policing. Considering the organised groups that the police confronted in the 1980s compared to the scattering of infantile looters in the summer of 2011, their inaction was all the more extraordinary. In this respect the riots were less about 'what has happened to today's youth?' than about what has happened to the British police force and to the sense of authority of the British establishment?

There are many reasons for the confusion of the police during the riots. A rise in the health and safety culture has affected policing to the extent that harm reduction becomes an issue in terms of assessing situations and even in terms of police officers' own diminished sense of duty over personal wellbeing. Also there has been a decline in a coherent 'establishment' response to disorder in society, with police officers ending up in court for actions at demonstrations. But there is clearly also something wider and deeper affecting the police force in terms of the overall coherent sense of meaning and purpose to their role in society - most particularly when it comes to issues of public order maintenance. At one level, and perhaps the most important level, the riots were the result of a declining authority amongst the elites, a confusion of authority of the police and consequently a visible vacuum of authority on the streets of England.

\section{THE 'UNDERCLASS'}

To focus on the response of the authorities to understand the riots is useful but only part of the issue. After all, despite rather pat attempts to pass off the riots as just another expression of greed, no different to greedy bankers or MPs fiddling expenses, there is something specific worth looking at in the riots and rioters themselves. This is not to argue that there is no connection between 


\section{Scottish Affairs}

today's elites and our so called 'underclass', there is, but this has more to do with the question of authority and its collapse than with the rather narrow question of greed.

We have already examined the nature of the rioting to some extent and questioned the motive force being greed or consumerism. It is equally worth questioning the representation of the riots as being based on a classical alienated angry young man, someone rebelling and kicking against the barriers and inequalities that he feels, even if in an incoherent way. Rather than anger or rage being expressed by the rioters, everything seemed a little more downbeat than that. There was a certain flippancy in much of the riots shown on television, a casual disregard for the property that was being burned down, and even a kind of superficiality about the rioting and looting itself. Whatever the riots were, except perhaps for the organised criminals who got involved (who at least had a purpose), most of the individuals involved did not appear to be very serious, or to recognise the seriousness of their actions. Despite the destructiveness of them, the riots felt strangely like a form of riot 'light', but this made them all the more depressing and disturbing.

Discussing the 'shallowness' of the anger and emotion shown during the riots, and the 'flimsiness of the sense of grievance', sociologist Frank Furedi argues that the most worrying thing about the riots was that they appeared to be nothing extraordinary to those involved, but simply an extension of the general and routine attitude, misbehaviour and destruction of property that goes on in certain communities in England on a daily basis. ${ }^{11}$ This was not, it is worth noting, for much of the time, the destruction of the property of the rich, or of the state, or of some specific type of group being targeted. It was, as the West Indian women attempted to point out to the rioters in Hackney, the destruction of their own community. As Brendan O'Neill, observes, even gangs historically had a sense of their own patch being something they would defend. Here in comparison, there was no patch as such, and there appeared to be no sense of community or of 'sharing and solidarity that once existed in working class communities'. ${ }^{12}$ The rioters were in the main infantile

\footnotetext{
${ }^{11}$ http://www.spiked-online.com/index.php/site/article/10985 [accessed 22nd Sept $2011]$

${ }^{12}$ http://www.spiked-online.com/index.php/site/article/10970/ [accessed $22^{\text {nd }}$ Sept 2011]
} 
narcissists; the looting itself being little more than an extension of their daily asocial and self involved existence.

\section{LIBERTY AND WELFARE}

For Furedi and O'Neill these particularly asocial youngsters are not a product of our so called neoliberal world, but are rather a product of the peculiar nature of the welfare state today. Implicit in the writings of Furedi more generally is an argument about the emergence of a new more degraded form of dependency being created in society and a constant undermining of the liberal notion of individual responsibility.

Historically the recognition of the need to give welfare support to families in times of need was balanced against an equally and arguably more important concern about self reliance and responsibility of individuals. Whatever the causes of poverty and whatever the reality of the potential for creating 'welfare dependency', the point is that historically elites in society have been concerned about undermining the morally responsible individual and have consequently and constantly promoted the idea of the autonomy of the individual and the family. Despite constant barriers to individual autonomy in society and despite constant state involvement in the family, these ideals and the ideal of the active self reliant human subject, were upheld in society.

This is what has arguably changed in the last few decades. Society has shifted towards a presumption not that people are and can be autonomous human subjects but that they are not and cannot. Rather than self reliance there is a presumption that we are all vulnerable and that we all need support with what we do, or have to be 'nudged' here and there to make the 'correct' choices.

One of John Stuart Mill's most liberating arguments was that the key thing for a liberal society to develop was not the right kind of behaviour as such, but the right kind of people. People may behave in all sorts of ways, they may make the wrong choices, they may drink, smoke and gamble to excess, or they may act in a violent manner or be antisocial and so on. None of this was good, but the far more important thing was that these people were responsible individuals. Not responsible in terms of their behaviour at all times, but responsible in that they were autonomous human beings who were aware that their actions were theirs. They were moral actors with the capacity to act both morally and immorally - and when immoral acts occurred they knew that they had been genuinely irresponsible. By cultivating morally responsible 


\section{Scottish Affairs}

individuals Mill believed a truly progressive liberal and free society could flourish, and indeed as a by-product people's behaviour would also become more civilised.

Mill may have underestimated the social barriers to genuine individual responsibility and liberty; however the principle of the responsible individual was and is an important one. Today the term responsibility is used ad nauseam but what is usually meant by this is not free choosing individuals being autonomous and responsible for their actions, but individuals' acting in a way that the government believes correct. Indeed government is now all about creating the right type of behaviour, rather than the right type of people. This was explicitly spelled out in the previous Labour government's focus upon what they called the politics of behaviour.

To create the 'right type of people' is a difficult task and is predicated first and foremost upon a strong sense of belief and purpose amongst those running society. However, as we have seen, the sense of purpose and authority in today's elites is at a low ebb, and consequently politics and policies in society have shifted towards a concern with the micro management of individuals' behaviour. Almost all problem and solutions to problems are understood in terms of managing relationships between people and directly or indirectly changing how they behave. Consequently self reliance has become not only disregarded, but is often seen as a problem, a barrier to the support we need to ensure the correct behaviour is followed. Likewise government has become ever more reliant upon laws rather than moral or political arguments to enforce correct forms of behaviour, thus undermining the genuine capacity of people to be free, to choose and to develop their independence and sense of personal responsibility.

\section{THE WellFARE StATE}

Welfare and the state's activities have changed in the last few decades. New categorise like well-being have emerged to assess and monitor our emotional state, our healthy behaviour, our fears and our happiness, often within the framework of a therapy culture (Furedi 2004) and a therapeutic state (Nolan 1998).

Despite the rhetoric of responsibility today the state has systematically moved increasingly into areas of life that were previously the preserve of private individuals. Through a more therapeutic framework and with a more 


\section{Wellfare Culture The English Riots And The Collapse Of Authority}

diminished sense of individual capacity broader and deeper forms of support have developed as have wider forms of regulation and monitoring of life. ${ }^{13}$

Parenting, for example, is no longer founded on the autonomy of the family, nor is there an expectation that parents can care for or discipline their children correctly without experts guiding them (Furedi 2001). Early intervention has become the key new policy development, predicated on the deterministic use of brain science; the capacity of children to deal with difficulties in early life, grow and develop as they get older has been abandoned, and a more systematic use of children's centres, parenting classes, health awareness raising and all matters concerning children's discipline have become problematised and professionalised. ${ }^{14}$

On the streets petty behaviour of youngsters has become the sole preserve of the police and council officials through the prism of 'antisocial behaviour' and the 'fear of crime'. Consequently, we are all discouraged from dealing with, or taking responsibility for, noisy neighbours and rowdy kids on our estates but have become trained to respond to all difficulties, especially with young people, through the state.

In schools the obsession with bullying and more recently relationship education has encouraged teachers to intervene and council pupils about their friendships and intimate relationships. ${ }^{15}$

${ }^{13}$ For the best discussion about the development of law and legal processes into
everyday life, see The Collapse of the Common Good: How America's Lawsuit Culture Undermines our Freedom (Howard 2001).

${ }^{14}$ See Waiton (2010) for a discussion about the growing involvement of 'expert' knowledge impacting and undermining both the more spontaneous relationships between adults and children in communities and also reducing the capacity of professionals to make moral judgements about their actions and relationships with youngsters.

${ }^{15}$ Ecclestone and Hayes have equally argued that therapy culture has infiltrated education, with the emotional fragility of young people become the caricatured framework around which education policies and practices have been developed. As early as the 1960s the American critic Edgar Friedenberg noted how therapeutic techniques were being introduced into U.S. schools by head teachers who were beginning to 'manipulate' rather than educate young people as their own belief in the meaning of education declined. 


\section{Scottish Affairs}

Even drug addicts are less inclined to expect to have to find their own drugs, and are now given their methadone by doctors and chemists over the counter. Once an addict of course, even of cigarettes, there is no expectation that we can resolve this problem ourselves, as addiction itself has been turned into a 'disease of the mind', an illness, that needs professional and often therapeutic support. Consequently the government and experts move in to help us by increasing the price of alcohol or forcing cigarettes under the counter of corner shops, nudging us to behave correctly.

Even at the level of welfare itself in terms of benefits, there has been a profound shift in the last few decades towards a situation where being out of work has become medicalised through sickness or incapacity benefits. ${ }^{16}$ From 463,000 people in 1981 there is now an estimated two million people in Britain on incapacity benefits. In the 2001 Census, ' 26 per cent of Glasgow's population indicated that they had a long term illness or disability limiting their daily activities or work, compared with 19 per cent in 1991'. In one survey of Glasgow adults on incapacity benefit fewer than one in ten were still looking for a job (Newlands et al 2004: 48-49). Observing the shift in benefit claiming, particularly sickness-related benefits, Professor Allan McGregor of Glasgow University has noted that it is now recognised that once people are on these benefits for more than two years, they are more likely to die or retire than to get a job. ${ }^{17}$ Consequently benefits for those out of work are no longer unemployment benefits as such, not a benefit for a transitional stage before work begins again, but rather have become a benefit for life. ${ }^{18}$

The uncomfortable reality, for anyone who is on the left of the political spectrum, is that the new wellfare state has created a situation where, for many, claiming benefits has become a way of life rather than a transitional support system into a life. It has also undermined the idea of the autonomous family, and at the same time the idea of being an active individual resolving problems in your own community has been all but whipped out, while children

\footnotetext{
${ }^{16}$ See Wainwright and Calnan (2002) for a discussion about Work Stress: The Making of a Modern Epidemic.

${ }^{17}$ See Newlands et al for a discussion about the continuing significance of sickness claimants in Glasgow despite, at times, the general improvement of employment prospects in the area (2004: 48).
}

${ }^{18}$ Professor McGregor was speaking on a BBC Scotland television programme entitled 100 years of the Broo $\left(7^{\text {th }}\right.$ September 2011). 


\section{Wellfare Culture The English Riots And The Collapse Of Authority}

are trained from an early age to resolve their problems with one another via teachers. At the same time, within schools, teachers are no longer expected to develop their own mechanisms for dealing with and disciplining unruly pupils, as guidance staff, outwith the classroom, increasingly become the first port of call for misbehaving youngsters.

\section{AUTONOMY AUTHORITY RESPONSIBILITY AND COMMUNITY}

One of the major problems with what has been discussed here is that not only do we face a situation where the elites have a diminished sense of authority, but adult authority more widely has been undermined, in part by the activities of the authorities themselves.

Society's more limited expectation of people has led to a situation where the most basic aspects of socialisation and the assertion of adult authority over the young have been compromised. Even for adults who are not hopelessly dependent upon the state there is a significant amount of self doubt and uncertainty now about how do deal with other people's children, and also with our own. In the more deprived parts of society these trends, which impact on all of us, are most profound and debilitating - undermining a sense of individual capacity, limiting the development of active autonomous adults, preventing the emergence of community leaders and destroying local norms and habits that help guide daily interactions with young people.

The socialisation that does occur is further undermined by checks, monitoring and code books that instruct any adult dealing with or working with children how to behave. For local adults on estates, in youth clubs or teachers in schools, it is less and less the case that they can rely on and develop their experience and character to become authoritative adults. Rather, rules, regulations, procedures, speech codes and even touch codes have developed, in part through the child safety agenda, which further undermine the more spontaneous and real relationships between adults and young people, relationships that can give meaning to both adults and young people alike. Consequently, the development of strong, confident and assertive adults in homes, communities and even schools is on the decline. Without this, there can be little sense of community as it becomes very difficult to establish norms and values grounded in the beliefs and actions of local people.

Finally, an additional problem is that without a clear sense of authority society is inclined to both fear and flatter the young. Indeed adults are more inclined 
to attempt to look like the young, dress and behave like them, rather than separate themselves off as mature individuals. In schools, a diminished confidence in the meaning of education and knowledge developed from the Enlightenment, coupled with these wider changes and the established sentiment that young people are a 'vulnerable group', has led education itself to often become a form of 'child centred' flattery, with failure becoming a problem, exams at times being labelled as a form of abuse and more generally the development of an ethos increasingly oriented around the self esteem of the child.

Unfortunately as Nolan (1998) has observed, the rise and rise of self esteem (or how young people $f e e l$ ), ahead of any wider moral or even social sense of right and wrong, has meant that young people in essence are encouraged to understand themselves with reference only to themselves. The result of this is that we get young people justifying the riots by explaining that, 'We'll respect you when you respect us', as if respect is a value free hand out that should be given gratis to anybody who demands it. ${ }^{19}$ But, of course, when young people have few if any authoritative adults, when they have literally no sense of connection with their community and when they are flattered and encouraged to understand the world through little more than their own self esteem, it is unsurprising that asocial narcissistic individuals emerge, grinning inanely at an old black woman shouting at them in the street as they set another shop alight. ${ }^{20}$

${ }^{19}$ Ironically, this model of respect was actually one promoted by the Labour government in their Respect Agenda (Waiton 2008, p. 158), and is also part and parcel of the discussion about recognition promoted by eminent sociologists like Richard Sennett (2004).

${ }^{20}$ In another rather depressing interview on BBC TV news a youth organiser explained that the problem for these young people was 'confidence and belief'. Unfortunately the likely attempt at therapeutic confidence building classes to build up the self esteem of those involved is unlikely to resolve the deeper problem of a lack of meaning and connection with society. The black youth sitting next to him (the success story who had been on the programme), equally depressingly explained that it had 'changed my mindset'. Again, the empty notion of the self (or the mindset) becomes the solution to problems, but no meaning to life can be gained in this way, no social or moral values of weight transferred. 


\section{SCOTLAND}

Now that we have discussed in some depth the case of the English we can get back to Scotland to think about why there were no riots here. Of course the above explanation was not done to fill space, but was an attempt to give some explanation about why the riots occurred in the first place. Relating this to Scotland then, my initial response to why Scotland is different is that it is not. Indeed to some extent the newness of the Scottish parliament, potentially unfettered by more traditional or liberal ways of doing things, could mean that it is inclined to be even more interventionist and 'supportive' and even more oriented around well-being and a therapeutic culture. The fetishisation of 'behaviour', early intervention, and self-esteem-oriented interventions, the community safety mentality and child safety obsession are all well established north of the border, and there is no indication that the elites in Scotland have any genuine understanding of or belief in individual responsibility or liberty, nor do they appear to have a deeper sense of purpose or authority. ${ }^{21}$

It is however possible that, due to the more static (and less dynamic) nature of Scottish society, some of the old vestiges of standards have remained in communities. Old liberals, Tories, socialists, welfarists and Christians may well be hanging on to their beliefs and ignoring or getting around all of the new 'correct' ways of relating to each other and to young people.

The less fluid nature of society may also mean that people remain geographically tied to their community and to older generations who again act as a buffer to both the fragmentary trends in society and against the wellfare dependency in all its forms. ${ }^{22}$ Migration from Glasgow has slowed considerably since the mid 1990s for example, from a high of 15,000 a year in the 1980s to 3,600 in the 1990s (Newlands et al 2004, p. 50). Common bonds may still support forms of solidarity and self reliance either financially or

\footnotetext{
${ }^{21}$ It is no accident that Carol Craig's influential book, The Tears that Made the Clyde, is subtitled, Well-being in Glasgow, illustrating the shift to 'well-being' as a significant category here in Scotland through which to develop policy and engage the public.

22 Scotland has historically been a country of net migration. This reduced in the $1960 \mathrm{~s}$ and by the late 1980s this trend was reversed as more people began to move to Scotland. This may however reflect less the fact that Scots are no longer leaving the country than the reality that there are more immigrants entering the country. See http://www.gro-scotland.gov.uk/files2/stats/high-level-summary/j11198/j1119806.htm [assessed 26th Sept 2011]
} 
through establishing norms of behaviour, in, for example, issues regarding children and child rearing.

However, the idea of wellfare dependency in inner city areas of London and other English cities does not suggest that these areas are themselves necessarily 'fluid' and made up of first generation residents to the area. Significance should perhaps be given less to geographic dispersal and disconnection than to the diminishment of moral independence and connections between generations facilitated by the wellfare state's relentless support and undermining of family self sufficiency in all its forms. Indeed, for the less dynamic sections of society who are less inclined to move to find work, both north and south of the border, and who remain in communities increasingly sustained and kept on a life support machine by myriad state professionals, initiatives and regulators, the potential for processes of 'antisocialisation' (Waiton 2010) and the creation of asocial communities are more intense (Waiton 2008, pp. 142-160).

Scottish nationalism may give some sense of identity to young people in Scotland (if at a more cultural than political level) and a connection to an ideal or outlook beyond their hoodies and demand for 'respect', although to what extent this has any depth of meaning is questionable. Perhaps more significant, especially for people living in and around Glasgow and Strathclyde, the region and city where you would perhaps expect most trouble to erupt if it was going to erupt anywhere, is the identity gained through football, specifically Celtic and Rangers, otherwise known as sectarianism.

Ironically, as the Scottish government is attempting to criminalise all things 'sectarian' surrounding Scottish football, it is possible that these identities, that are religiously shallow today and also far less politically significant following change in Northern Ireland, still give a relatively large number of people a certain sense of community and commonality. Here we have, to varying degrees, a wider sense of connection, duty and loyalty. People may not like the 'sectarianism' or more significantly the cultural and to some extent political affiliation to Britishness and Irishness associated with these football teams and traditions, but we tend to forget that what often makes a community strong is its self identity in opposition to another group in society. However, the fact that the so called 'sectarian problem' is today far more of a football issue than one (especially for younger generations) associated with politics or religious beliefs and organisations suggests that this type of identity is relatively weak (after all, it is only a game). Perhaps there is also, in part because of the football/sectarian framework of the West of Scotland, a certain identification 


\section{Wellfare Culture The English Riots And The Collapse Of Authority}

with the region itself and especially with the city of Glasgow and with yourself as a Glaswegian - something that can (especially at a football level) compete with Scottishness as an identity.

It is debatable to what extent these belief systems and forms of identity exist today or have real purchase, especially in poorer areas of Scotland. But as you will note, the point here is to look at what may act as a social glue and a barrier to the more asocial, post modern forms of narcissism across society and especially amongst the young.

Perhaps a further 'advantage' Scottish cities have over a number of English cities is the more limited number of ethnic minorities in the country. This is potentially a problem not because of the 'problem of blacks', or of 'black culture' as there is no black culture as such. The problem is more that professionals and experts who deal with 'ethnic' young people are inclined to be particularly acutely relativistic, non-judgemental and defensive about challenging the infantile urban 'gang' culture associated with black youth (but which incorporates many white and some Asian youth as well). Whereas the West Indian woman in Hackney will shout and ridicule the immature warring 'bad man', the 'Wire'-watching cultural elite are more inclined to kowtow to these youngsters and attempt to degrade education, knowledge or standards by for example attempting to make everything 'relevant'. So, for example, we end up with the clichéd production of Romeo and Juliet as a story about street gangs all done to rap. ${ }^{23}$ Although this is a general trend affecting all young people, the potential for these, often inner-city, young people to be patronised, 'therapised' and never seriously challenged with any standards or framework of meaning beyond their own self and 'their culture' is arguably greater than any other section of society.

In Scotland relativism and multi-culturalism have a number of problems illustrated through the 'One Scotland many Cultures' campaign but, despite the somewhat artificial state sponsoring of 'Muslim culture' in the last few decades, these communities in Glasgow's Southside for example appear to

${ }^{23}$ Discussing the ridiculous trousers hanging off your backside trend with a friend who lives in London, she explained with horror that one of her child's primary school teachers dressed in this way. We both wondered whether this would happen in Scotland and thought it was possible but less likely. The story had a happy ending however, as this new teacher was not invited back after his first years work in the school. 


\section{Scottish Affairs}

have a more interconnected form of community or are at least one less dominated by a narcissistic and debilitating wellfare culture. ${ }^{24}$

\section{CONCLUSION}

The above discussion about Scotland hopefully adds to the themes and problems I have attempted to outline in this article. I have briefly and speculatively discussed ways in which Scotland may be different from England but if I was to bend the stick and say which side of the rioting fence Scotland sat I would argue that the differences are less significant than the similarities so don't hold your breath.

The examples used above and the type of young people focused upon are important, but more as a way to take a look at the authorities today, at various elite groups, at professionals, but also at the adult world more generally. It is the changes in the way the authorities relate to both adults and young people, often through the patronising framework of the newly formed wellfare culture, that has helped create the profound level of professional micro management of everyday life. The result is that autonomy and independence as a norm have been undermined (indeed nobody even bothers talking about the 'autonomous family' today). Consequently the role of adults, their active capacity, their strength and leadership, and ultimately their ability to socialise the young, have been warped and weakened. When new youth workers, teachers, adult volunteers or even new parents find themselves reaching for a manual to help them understand how to socialise children we can be sure that genuine meaningful socialisation no longer exists.

Looking back at the relatively few critical portrayals of this emerging culture, one of the best illustrations of the cowardly nature of modern elites was demonstrated by the comedy character Ali G, a mock black rapper who when interviewing influential British and American individuals was rarely

\footnotetext{
${ }^{24}$ The relativistic promotion of 'Muslim' organisations and identity in both England and Scotland has the potential for 'fossilising' this identity (Furedi 2011) and with this the limitations of non-judgemental approaches are possible. However, at the same time, there does appear to be a form of collective community outlook encouraged amongst, for example, Pakistani immigrants in Glasgow. This may limit the more fragmentary, dependant and narcissistic identity of some groups in inner city areas in London and other English cities. (For a discussion on the meaning of race in the Southside of Glasgow see work by Virdee, Kyriakides, Modood.)
} 
challenged about his sexism, homophobia, racism and general infantile stupidity. The interviewees were too keen to 'get down' with Ali G and too nervous about being challenged themselves by Ali $G$ asking 'is it cos ah is black'. Interestingly one of the few people to challenge Ali G consistently and actually illustrate a belief in their own arguments and in the possibility that Ali $\mathrm{G}$ could be changed through reasoned discussion was the old socialist Tony Benn. At the end of the interview Ali G instead of trying to make Benn do a fist pump - which was how he ended all other interviews - came out of character (unbeknown to Tony Benn) and shook his hand. 'Respect' was Ali G's comedy catch phrase - but this time his interviewee had earned genuine respect by standing up for what he believed in rather than degrading himself as the others had done.

\section{REFERENCES}

Baudrillard, J. (1983) In the Shadow of the Silent Majorities: Or, the End of the Social and Other Essays. London: MIT Press.

Craig, C. (2010) The Tears that Made the Clyde. Well-Being in Glasgow. Glasgow: Argyle.

Ecclestone, K. and Hayes, D. (2009) The Dangerous Rise of Therapeutic Education, London: Routledge.

Friedenberg, E.Z. (1959) The Vanishing Adolescent. Dell: New York.

Furedi, F. (2004) Therapy Culture: Cultivating Vulnerability in an Uncertain Age. London: Routledge.

Furedi, F. (2001) Paranoid Parenting. Suffolk: Penguin.

Howard, P.K. (2001) The Collapse of the Common Good: How America's Lawsuit Culture Undermines our Freedom. New York: Ballentine.

Newlands, D., Danson, M. \& McCarthy, M. (eds) (2004) Divided Scotland: The Nature, Causes and Consequences of Economic Disparities within Scotland. London: Ashgate.

Nolan, J. (1998) The Therapeutic State: Justifying Government at the Century's End. New York: NY University Press.

Sennett, R. (2004) Respect: The Formation of Character in an Age of Inequality. London: Penguin.

Tompson, K. (1988) Under Siege: Racial Violence in Britain Today. London: Penguin. 
Virdee, S., Kyriakides, C. \& Modood, T. (2006) 'Codes of Cultural Belonging:

Racialised National Identities in a Multi-Ethnic Scottish Neighbourhood', in Sociological Research Online, Volume 11, Issue 4.

Wainwright, D. and Calnan, M. (2002) Work Stress: The Making of a Modern Epidemic. Milton Keynes: OUP.

Waiton, S. (2008) The Politics of Antisocial Behaviour: Amoral Panics. London: Routledge.

Waiton, S. (2010) 'The Antisocialisation of Children and Young People: Undermining Professionals and Colonising Everyday Life', in Youth and Policy, No.105, pp. 37-49.

September 2011 